\title{
A comparison of soil moisture relations between standing and clearfelled plots with burnt and unburnt harvest residue treatments of a clonal eucalypt plantation on the Zululand Coastal Plain, South Africa
}

\author{
SB Dovey ${ }^{1 *}$, W de Clercq ${ }^{2}$ and B du Toit ${ }^{3}$ \\ ${ }^{1}$ Sustainable Forest Productivity Research, Institute for Commercial Forestry Research, Private Bag X1, Matieland 7602, South Africa \\ ${ }^{2}$ Department of Soil Science, Stellenbosch University, Private Bag X1, Matieland 7602, South Africa \\ ${ }^{3}$ Department of Forest and Wood Science, University of Stellenbosch, South Africa, PO Box 100281, Scottsville 3209, South Africa
}

\begin{abstract}
The effects of clearfelling and subsequent residue retention or burning on water and nutrient balances needs to be understood and quantified on forest sites that are sensitive to loss, so that the long-term sustainable productivity of such sites can be maintained and promoted. An experimental site was established in a clonal eucalypt compartment on the Zululand Coastal Plain, to compare changes in water fluxes through the mature undisturbed eucalypt stand with those after felling and re-planting, under 2 conditions: burning, and retention of the harvesting residues. The study was located in an area of high rainfall and high stand productivity, with sandy soils and low soil carbon and nutrient status; chosen so that the effects of intensive demands on water and nutrient fluxes on a potentially sensitive site could be investigated. This paper presents only the hydrological component of the study. Data collection included weekly determination of rainfall, throughfall, stemflow and soil moisture fluxes from the surface to a depth of $1 \mathrm{~m}$. Drainage rates through the profile were established using time domain reflectometry probes while water drainage volumes were assessed using shallow plate lysimeters. Despite slow growth in the unfelled crop during the monitoring period (attributed to a pest infestation), soil moisture depletion remained rapid and drainage below $1 \mathrm{~m}$ remained low. Soil moisture was recharged within a few months after clearfelling, but became rapidly depleted as the canopy of new crop developed and approached canopy closure. A decreased wetting-front velocity and a marginally higher field capacity were proposed as evidence of pore clogging that appeared to occur during the inter-rotation period. The soil profile under the unburnt residue maintained a marginally higher soil moisture status and lower drainage than the soil profile under the burnt residue. Although soil moisture and drainage in the burnt and unburnt residue treatments became similar to the unfelled crop from canopy closure onwards, rainfall additions to soil moisture were depleted faster under the new crop during the first few months after canopy closure. Small differences in soil moisture status between the burnt and unburnt residue treatments presented here may not be sufficient to influence residue management decisions. The length of the inter-rotation period and practice of residue burning may, however, need consideration where soil carbon and nutrient loss or displacement may negatively affect the sustainability of the site.
\end{abstract}

Keywords: Soil moisture drainage, residue burning, post felling, inter-rotation

\section{Introduction}

Water use under commercial plantation forestry has been extensively studied in South Africa with the outcomes used to formulate guidelines for water use charges and regulations (Dye and Versfeld, 2007). These regulations, an increased demand for wood products, and numerous other political, economic and environmental factors, have pressurised the industry to seek innovations to enable larger quantities of timber and biomass to be produced from a decreasing land base (FSA, 2009). The loss of land area (9\% between 1999 and 2009, FSA, 2009) has occurred through, inter alia: wetland delineation, successful land-claims that have subsequently resulted in land being converted out of forestry, and the establishment of wildlife corridors through plantation forest areas. Increases in productivity of $19 \%$, for the same 10 -year period, have been realised through the selection of faster growing trees, improved

\footnotetext{
* To whom all correspondence should be addressed.

of +27 33 386-2314; fax: +27 33 386-8905; e-mail: steven.dovey@icfr.ukzn.ac.za

Received 22 November 2010; accepted in revised form 7 October 2011.
}

matching of tree species to sites for optimal timber growth, planting of disease-resistant clonal varieties, shorter rotation lengths, more intensive silvicultural practices, and mechanisation. This has also substantially increased the rate and quantity of biomass removal per unit land area of plantation forests and consequently increased pressure on water and nutrient resources on the remaining land area. It is therefore crucial that the negative impact of a greater demand on water be understood and quantified so that long-term sustainable productivity can be maintained and promoted.

Soil moisture is rapidly utilised under forestry with little evidence of long-term soil or ground water recharge under full-canopied eucalypt crops, as dynamic equilibrium is maintained between stomata and leaf area index controls of evapotranspiration and soil moisture availabily (Dye, 1996; Kienzle and Schulze, 1992; Laclau et al., 2001). Tracking the processes within the hydrological component of a commercial plantation forest requires knowledge of the magnitudes of the water fluxes, tree water use, and the impact of site management on these fluxes. Site management at harvesting, and the conservation, displacement or loss of harvest residues through removal or burning during the inter-rotation phase, can potentially impact a site. As the hydrological cycle is a key driver of 
forest nutrient fluxes and cycles, the effect of clearfelling and subsequent residue management on soil moisture and drainage may impact on water availability to the subsequent crop and nutrient loss or displacement from the active fine root zone (top $50 \mathrm{~cm}$ of soil) (Carlyle and Nambiar, 2001; Smethurst and Nambiar, 1990). This is in addition to nutrient and carbon losses that occur through harvesting and residue burning. Water repellency of soils, which is common under eucalypt plantations, may be increased with residue burning, reducing infiltration rates, increasing surface runoff and soil erosion on sloped lands (DeBano, 2000; Scott, 1993; Scott, 2000; Scott and Van Wyk, 1990).

The deep sandy soils of the Zululand coastal ecosystem (Northern KwaZulu-Natal, South Africa) are low in clay, organic carbon content, nutrient and water storage capacity, and have high drainage rates (Hartemink and Hutting, 2005). These soils are unable to buffer chemical, physical and organic (biological) changes, placing them at risk of degradation, ultimately limiting or reducing tree productivity under poor site-management practices. The sustainability of management practices on sites which have high productivity but low soil moisture and nutrient storage capacity is increasingly questioned, particularly under currently prescribed residue-burning operations.

A study was initiated to compare soil moisture content and drainage volumes (using in situ measurement techniques), in a mature clonal eucalypt stand, with those after felling, and upon which residue burn and no-burn management practices were imposed, and for the first 18 months of new crop growth. In addition, a soil moisture model (Hydrus 1D) was calibrated with soil moisture content measured at each depth to verify the predictive ability of the model used. This study forms part of a larger study that aimed to determine the impact of site management on long-term sustainable productivity with respect to natural and management-induced nutrient losses and gains. The model will be discussed in future publications as a tool to predict drainage fluxes. Water fluxes will be multiplied by measured dissolved nutrient concentrations to estimate nutrient fluxes due to gravity drainage, in a similar manner to that used by Laclau et al. (2007).

\section{Materials and methods}

\section{Study site}

The site selected was located on the Zululand coastal plains (northern KwaZulu-Natal, South Africa) where extensive areas of sandy structureless albic arenosols and a sub-tropical climate result in areas of low soil fertility (Fey and Hughes, 2010), but high productivity potential. The experiment was initiated at the end of 2007 in a 17.6 hectare compartment of 7-year-old clonal Eucalyptus grandis $x$ camaldulensis in the Siyaqhubeka-owned Dukuduku plantation (Fig. 1). The site was converted (circa 1955) from a mosaic of indigenous lowland coastal forest and grassland to commercial forestry. Using the climatic data of Schulze (1997), the study area is characterised by a relatively high and variable seasonal (summer) rainfall (mean annual precipitation (MAP) of $920 \mathrm{~mm}$ ), mean annual temperature (MAT) of $21.7^{\circ} \mathrm{C}$, APAN evaporation of $1814.5 \mathrm{~mm}$. Soils are deep ( $>30 \mathrm{~m})$, free-draining sandy soils $(<5 \%$ clay) with a low organic carbon content $(<1 \%)$. The site is $62 \mathrm{~m}$ above sea level and $15 \mathrm{~km}$ inland from the coast (Indian Ocean), with its centre at $28^{\circ} 17^{\prime} 51^{\prime \prime} \mathrm{S}$ and $32^{\circ} 18^{\prime} 55^{\prime}$ ' E. Although the nearest perennial river is found approximately $6 \mathrm{~km}$ to the east, the site is

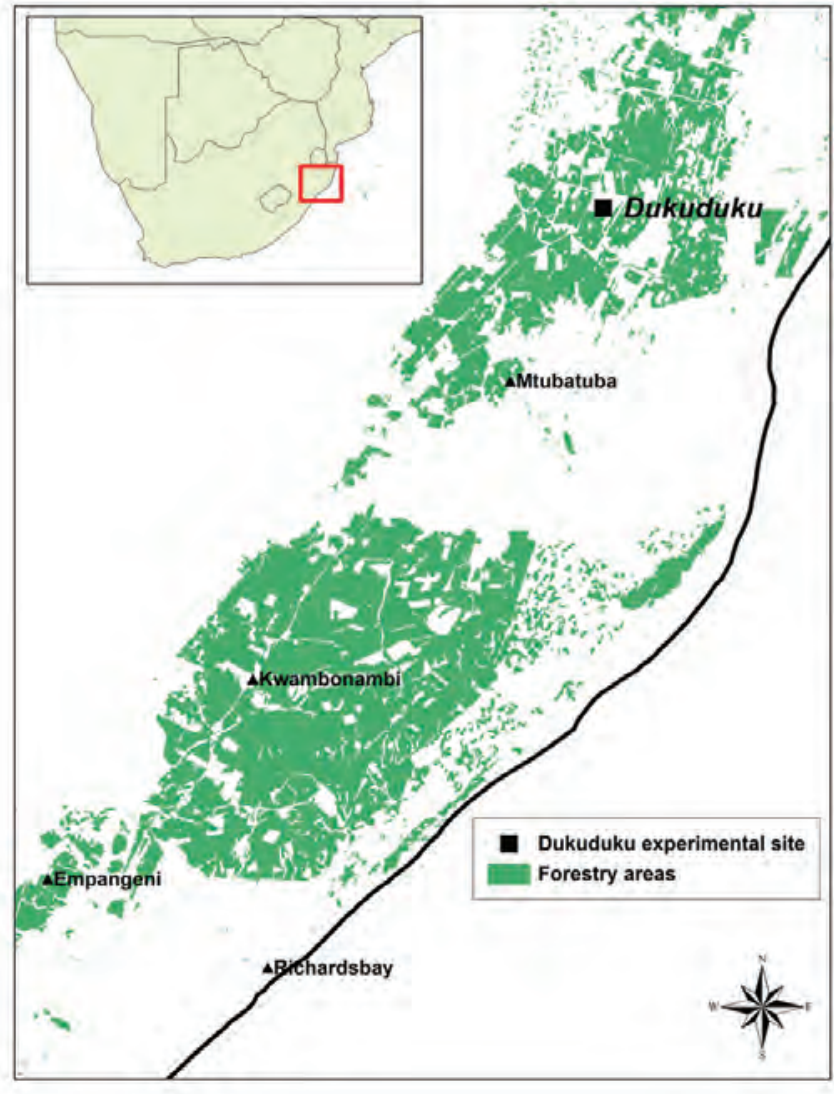

Figure 1

Map showing the location of the plantation area in southern Africa and the study site location within KwaZulu-Natal commercial plantation forestry areas

$1.3 \mathrm{~km}$ from the nearest delineated wetland area, the centre of which is at $45 \mathrm{~m}$ above sea level. The slope of the land is relatively flat with an incline of $0.17^{\circ}$.

The trees were originally planted at a spacing of $3 \mathrm{~m} \times 3 \mathrm{~m}$ in a rectangular compartment ( $92 \times 213$ trees) that was chosen as having its long axis as close to a north/south orientation as possible (Fig. 2). Tree volume at 7 years was derived from tree height and diameter at $1.3 \mathrm{~m}$ above ground level (dbh) using tree volume and taper functions of Morley and Little (2011) as $143 \mathrm{~m}^{3} \cdot \mathrm{ha}^{-1}$ for 1102 trees $\mathrm{ha}^{-1}$ (99\% survival). The site index at base age 5 (SI $_{5,80}$ th percentile of tree heights projected to 5 years of age) for this compartment was estimated as 19.9 using the data of Coetzee (1992). Site index, a tree growth-based measure of site quality, was within normal ranges typical for this area (Smith et al., 2005). The tree canopy in the unfelled plots was also infested with Thaumastocoris peregrinus, peaking during the summer months of January to March each year. This insect pest reduces photosynthetic activity in the canopy and may cause increased litterfall (Nadel et al., 2010). Evidence of Gonipterus spp., a leaf-eating insect that reduces leaf area and apical growth, was also found.

\section{Design and layout}

Water fluxes were monitored as precipitation, throughfall and stemflow, interception of precipitation by the trees, soil moisture content and drainage to $100 \mathrm{~cm}$ below the soil surface. The effects of commercial forest management practices on these water fluxes were monitored through the felling, residue 


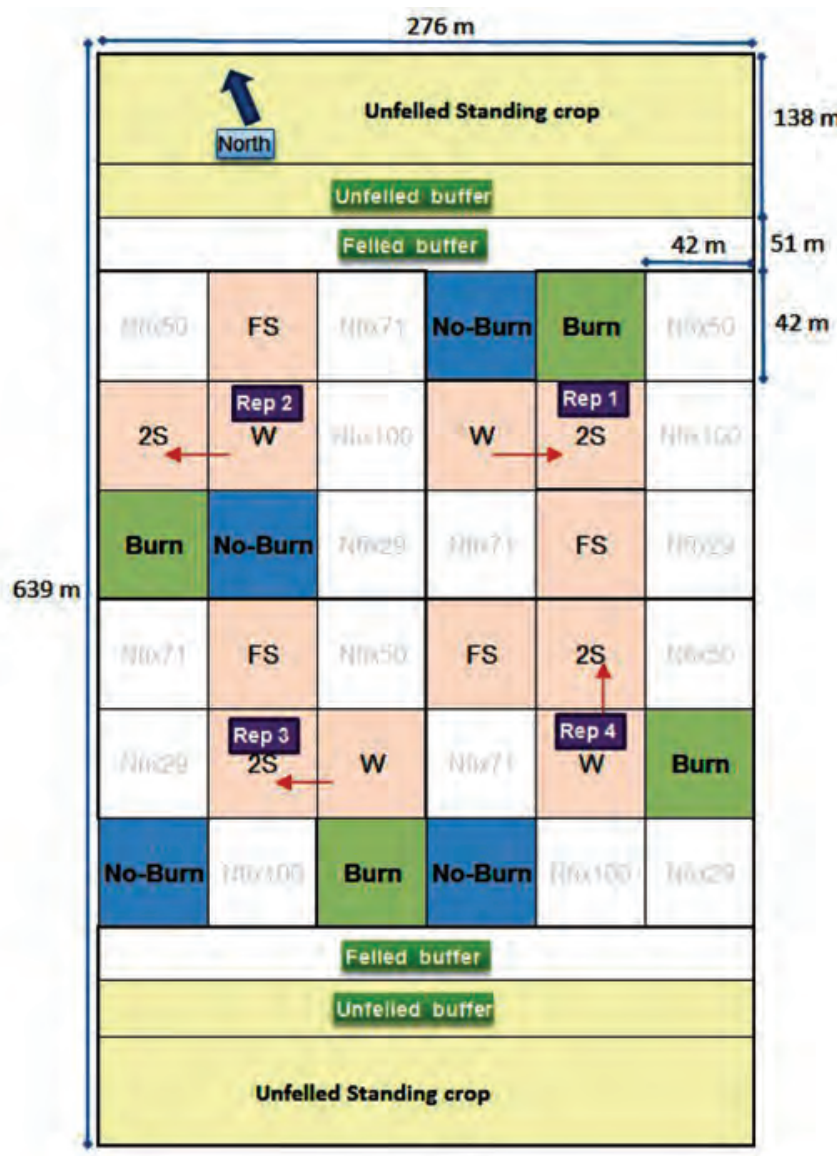

Figure 2

Experimental layout of treatment plots showing the standing crop zones and internal felled Burn and No-Burn treatment plots with dimensions given in metres. Additional treatment codes apply to further components of this study not reported here (W as whole tree harvest, FS - No-Burn plus fertiliser replacement, $2 S$ - double residue layer).

management, and re-establishment phases of the plantation cycle. A number of post-harvest residue treatments were applied to the full study site after felling. For the larger study, 9 treatment plots were established with 4 replicates and arranged in a randomised complete block design (Fig. 2). The crop on either side of the felled experimental area was not clearfelled and was used as 2 replicates of a standing crop treatment (Fig. 2). The treatments within the full experiment included various levels of residue and nutrient management that are not considered or reported on here. Treatments selected for intensive monitoring were the burn and no-burn residue treatments and the standing areas. These were considered to represent the most extreme practices of the normal residue management operations, while the standing areas were used to represent the site without a harvesting disturbance.

The experimental site was established at the end of 2007 with the majority of the equipment installed on 2 replicate sub-plots of each of the 3 treatments to be investigated: viz., standing crop (SC), residue burned (Burn) and residue retained (No-Burn) (Fig. 2). Installation of equipment commenced a full year prior to felling, allowing adequate time for soil and equipment stabilisation. The SC areas were delineated as $46 \mathrm{x}$ 92 tree $(138 \times 276 \mathrm{~m})$ zones at the northern and southern end of the compartment with a surrounding buffer zone of $51 \mathrm{~m}$ width (17 trees) which was clearfelled. SC plots were delineated in central positions of the northern and southern areas, with buffer zones of 17 trees. The north/south orientation and the large buffer areas were designed to minimise the intrusion of additional shading and/or solar penetration between felled and SC plots. The central portion of the compartment was felled, and divided into 36 square experimental plots $42 \times 42 \mathrm{~m}$, each with an internal 15 x 15 m plot used for tree growth measurement. Felling of the buffer zone began in September 2008. The buffer areas were used as extraction routes for the main felling operation at the end of November 2008. Timber was manually stacked in early January 2009 and mechanically extracted, with residues manually broadcast during felling. Burn treatments were carried out in early March 2009 on a hot cloudless day under light, windy conditions to induce a rapid complete burn. The site was manually pitted and Eucalyptus grandis $\mathrm{x}$ urophylla clones were planted at the end of July 2009 at a 3 x 2 m espacement. Weed and coppice re-growth was initially managed by manual slashing, and then chemically eliminated before planting.

\section{Data collection}

A fully-automatic Campbell Scientific weather station was installed in an adjacent open area to record rainfall, temperature, relative humidity, solar radiation, wind speed and wind direction. Data were collected at hourly intervals and summarised daily. Three white plastic funnels (14.1 cm diameter) were installed at $1.2 \mathrm{~m}$ above the ground (4 replicates) in the felled plots to collect precipitation, and similarly in the unfelled plots to collect throughfall (Fig. 3a). Tree diameter at $1.3 \mathrm{~m}$ above ground level (dbh) frequency distribution was considered in selecting a 4 x 4 tree sub-plot into which the equipment was installed. This was done to distribute the collectors under a range of tree canopies that represented the full range of tree size classes found across the study site. This design was utilised considering the uniform canopy of the clonal eucalypt crop, the intended use of the samples in water quality assessments and acceptable error limits of the design (Kimmins, 1973; Lawrence and Fernandez, 1993; Mululo Sato et al., 2011). Water drained from the funnels via polyurethane tubing was collected and stored in $5 \ell$ white high-density polyethylene (HDPE) bottles. A small piece of plastic mesh was placed in each funnel to prevent detritus from entering the tubing. The bottles were collectively housed in a $25 \ell$ white HDPE bucket, buried to protect the bottles from heat and sunlight, with only the lid exposed. Four size classes of tree diameter were selected using the tree diameter distribution, and a single tree was selected from the midpoint of each class, onto which stemflow collectors were installed. The stemflow collectors (Fig. 3b) were slotted $20 \mathrm{~mm}$ polyurethane tubes attached to each of the 4 trees draining into separate $5 \ell$ bottles contained in a partially buried $30 \ell$ bucket (Levia and Frost, 2003). The tubes spiralled each tree twice from 0.6 to $1.4 \mathrm{~m}$ above ground level, held fast to the tree with plastic packaging belt threaded through the tube. Contact between the tree and tube length was achieved using a silicone sealant.

A crescent-shaped trench was excavated to a depth of $1.2 \mathrm{~m}$ to allow measurement of soil moisture status and flux on the site (Fig. 3c). The trench was situated between the trees so that the wall of the pit gave access to the inter-row of 6 trees, the front of the crescent facing 2 trees, the arms turning diagonally across the intra-row of 2 trees each. This was done to allow access to undisturbed soil at the pit face while allowing the pit face to cover as much soil and tree size variability as 


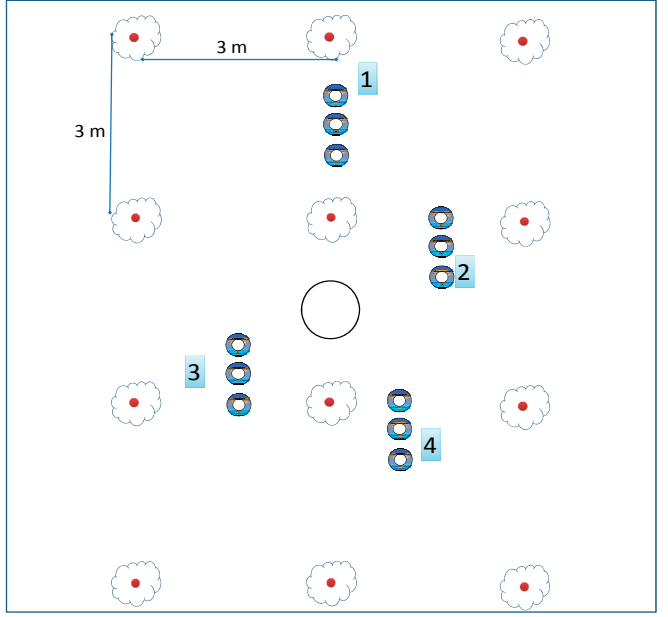

\section{- Tree position \\ - Collection funnel Buried storage bucket}

(a)

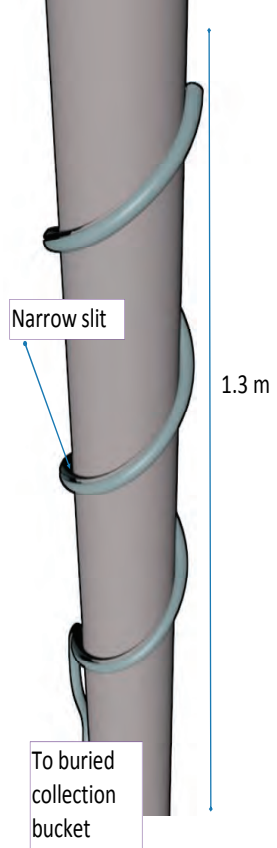

(b)

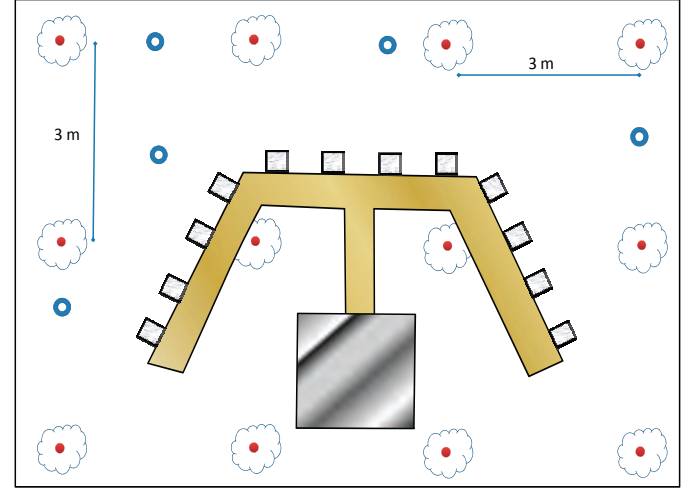

- Tree position

- Profile probe positions (relative)

$\square$ Covered collection pit

$\square$ Lysimeter plate

Backfilled trench

(c)

Figure 3

(a) Layout of a funnel cluster and storage container relative to tree positions. (b) Side view of a narrowly-slit stemflow collection tube attached to a tree stem. (c) Top view, layout of trench and storage pit relative to tree positions, showing lysimeter plates that are alternatively buried 15, 50 and $100 \mathrm{~cm}$. Profile probe positions shown relative to trees.

possible. Four replicates of zero tension plate lysimeters (30 cm x $30 \mathrm{~cm}$ ) with $3 \mathrm{~cm}$ walls on 3 sides were inserted horizontally at depths of $15 \mathrm{~cm}, 50 \mathrm{~cm}$ and $100 \mathrm{~cm}$, into the wall of a trench, by opening a narrow envelope into the pit face at each depth. Horizontal distances between plates were maintained at no less than $60 \mathrm{~cm}$. Plates were used as a cost-effective method to collect a sample of drainage water for water quality diagnosis, although they are known to have a collection efficiency of about $10 \%$ (Weihermuller et al., 2007). This was assumed to give an integrated sample of gravity-drained soil solution, but necessitated the prediction of actual drainage using the soil moisture flux model described later. The depths chosen here were intended to reflect normal fine root length and mass density distributions characteristic of the soil under eucalypts. Highest densities in clonal eucalypts have been shown to occur in the first $15 \mathrm{~cm}$ of soil, decreasing markedly with depth to $50 \mathrm{~cm}$ and steadily to $1 \mathrm{~m}$ and beyond where very few fine roots are found (Gonçalves and Mello, 2004; Knight, 1999; Laclau et al., 2001; O'Grady et al., 2005). Prior to insertion, soil from the envelope was placed as slurry into the plate, the plate pressed to the top of the envelope to make best contact, and the gap under the plate was filled with the remaining soil. The plates were installed at a slight angle to allow for drainage to a corner plug connected to a polyurethane tube. A trench dug from the centre of the crescent led into a pit excavated to $1.4 \mathrm{~m}$, which allowed the 4 plates at each depth to gravity drain to plastic collection bottles. The crescent trenches and inter-leading trenches were carefully backfilled ensuring no disturbance of the area above the installed plates. The walls of the access pits were reinforced with timber and the pits were covered with a corrugated lid to offer protection from sunlight and rainfall.

Water was collected from all water collectors on a weekly basis from December 2007 to July 2010, and the volume measured. A soil capacitance profile probe was used to measure volumetric soil moisture content at weekly intervals at 10,20, $30,40,60,80,100 \mathrm{~cm}$ below the soil surface via 5 access tubes installed into each plot. A micro-topography was apparent over the entire site, possibly caused by lifting of soil near to trees, relative to the soil level of the spaces between trees ( 5 to $10 \mathrm{~cm}$ amplitude). The access tubes were therefore placed within and between the tree rows to represent the variability of soil moisture in each plot (Fig. 3c). Time-domain reflectometry (TDR) probes were installed in one of each of the treatment plots at $15,50,75$ and $100 \mathrm{~cm}$, automatically recording volumetric soil moisture content at hourly intervals via a custom-built data-logger.

Soil samples for gravimetric moisture analysis (oven drying at $105^{\circ} \mathrm{C}$ until constant mass) were collected periodically to validate soil moisture contents measured with the electronic devices. Further soil samples were collected from each treatment plot at 4 weekly intervals by inserting five $40 \mathrm{~cm}$ PVC cores of $5 \mathrm{~cm}$ internal diameter into each plot, to a depth of $30 \mathrm{~cm}$. Soils were separated into layers of 0-5, 5-15 and 15-30 $\mathrm{cm}$ depths. Cores were also inserted at various positions between the trees to represent the variability of soil microtopography, while avoiding timber extraction routes and areas disturbed by prior sampling. These soil samples collected formed part of a nitrogen mineralisation and soil carbon and chemical change component of the broader study, the results of which are not discussed here. A simple semi-quantitative assessment of water repellency was conducted using a water dropper to apply 6 droplets of deionised water to a smoothed surface of a sub-sample of the air-dried soils collected from each of the treatments. The time taken until the water drops were absorbed (infiltration) into the soil was recorded and the average time used as an indicator of water repellency (Letey et al., 2000; Scott, 2000). 


\begin{tabular}{|c|c|c|c|c|c|c|c|c|c|c|}
\hline \multicolumn{11}{|c|}{$\begin{array}{c}\text { Table } 1 \\
\begin{array}{c}\text { Mean values of soil organic carbon, texture, and bulk density taken at incremental } \\
\text { depths and soil moisture retention and conductivity parameters }\end{array}\end{array}$} \\
\hline $\begin{array}{c}\text { Sample } \\
\text { depth }\end{array}$ & $\begin{array}{l}\text { Organic } \\
\text { carbon }\end{array}$ & Clay & Sand & Silt & $\begin{array}{c}\text { Bulk } \\
\text { density }\end{array}$ & $Q r$ & Qs & Alpha & $n$ & Ks \\
\hline$(\mathrm{cm})$ & $\%$ & $\%$ & $\%$ & $\%$ & $\mathbf{g} \cdot \mathrm{cm}^{-3}$ & $\mathrm{~cm}^{3} \cdot \mathrm{cm}^{-3}$ & $\mathrm{~cm}^{3} \cdot \mathrm{cm}^{-3}$ & $\mathrm{~cm}^{-1}$ & - & cm $\cdot$ day $^{-1}$ \\
\hline $0-20$ & 0.43 & 2.5 & 94.5 & 3.0 & 1.53 & 0.0373 & 0.3778 & 0.0499 & 2.4853 & 728 \\
\hline $20-40$ & 0.27 & 2.3 & 95.3 & 2.4 & 1.55 & 0.0374 & 0.3732 & 0.0498 & 2.4657 & 733 \\
\hline $40-60$ & 0.21 & 2.2 & 96.0 & 1.8 & 1.57 & 0.0375 & 0.3683 & 0.0497 & 2.4473 & 719 \\
\hline $60-80$ & 0.18 & 1.8 & 95.9 & 2.3 & 1.59 & 0.0376 & 0.3628 & 0.0496 & 2.4297 & 688 \\
\hline 80-100 & 0.16 & 2.0 & 96.2 & 1.7 & 1.61 & 0.0375 & 0.3569 & 0.0495 & 2.4129 & 639 \\
\hline $100-120$ & 0.15 & 2.6 & 96.2 & 1.2 & 1.64 & 0.0374 & 0.3505 & 0.0493 & 2.3969 & 572 \\
\hline
\end{tabular}

Harvest residue and tree biomass accretion was estimated using 20 destructively-harvested trees selected from across the entire site prior to felling and at 6-monthly intervals in the new crop. Masses were scaled from individual trees to a per-hectare scale using allometric relationships developed between tree diameter, height and mass of each tree component. Forest litter layer and residue biomass was collected at 4-weekly intervals from 5 randomly-selected samples taken using a metal ring of $34 \mathrm{~cm}$ diameter. Samples were dried at $60^{\circ} \mathrm{C}$ to constant mass prior to dry mass determination. The loss on ignition (LOI; samples ashed at $450^{\circ} \mathrm{C}$ for $12 \mathrm{~h}$ ) was used to estimate the fraction of soil contamination in the litter layer samples. The ring method was used, in conjunction with 15 metal plates inserted under the residue in each plot, to assess biomass prior to burning and the loss of biomass and ash remaining after burning. Litterfall was assessed using 3 randomly-located 1.5 x 1 m litter-fall traps.

\section{Model prediction of water content and drainage}

The 1-dimensional Hydrus 1D soil moisture model (Šimůnek et al., 2008) was parameterised for the study site and used to predict daily soil moisture content and drainage at each depth. Hydraulic conductivity parameters were estimated using a neural network prediction after Schaap and Bouten (1996) with matrix potential measurements of a similar soil taken from Rietz (2010) and soil textural fractions and bulk density determined from samples taken at the site (Table 1). Soil hydraulic parameters are presented in Table 1 as residual and saturated soil moisture content ( $Q r, Q s$, respectively), parameters in the soil moisture retention function (Alpha, n), and saturated hydraulic conductivity (Ks). The van Genuchten-Mualem soil hydraulic model was used as the hydraulic conductivity component of the model (Van Genuchten, 1980). Evapotranspiration was estimated using the Penman-Monteith equation for the model and meteorological data collected at the site, and also evaluated using TDR data recorded at the site. Leaf area index recorded at the site through destructive methods was allowed to fluctuate according to optically-determined LAI-2000 measurements and values given in Dye et al. (2004). A radiation extinction coefficient of 0.4 and an albedo of 0.2 were used (after Stape et al., 2004b) for the unfelled trees. An albedo of 0.3 was used during the fallow period in the felled area (Ten Berge, 1986). Rainfall was adjusted for interception using a relationship developed between weekly rainfall and weekly canopy drainage from data collected at the site. Interception of rainfall by the litter and residue layers was estimated for the unfelled tree litter layer and the felled crop residue layer using relationships between residue mass and interception, after Paul

\begin{tabular}{|l|c|c|c|}
\hline \multicolumn{4}{|c|}{$\begin{array}{c}\text { Table 2 } \\
\text { Relationships between rainfall collected in an open } \\
\text { area and that collected with throughfall and stemflow } \\
\text { derived through linear regression }\end{array}$} \\
\hline Statistic & Throughfall & Stemflow & $\begin{array}{c}\text { Canopy } \\
\text { drainage }\end{array}$ \\
\hline Constant & $-1.404^{* * *}$ & $0^{\text {ns }}$ & $-1.462^{* * *}$ \\
\hline Slope & $0.9076^{* * *}$ & $0.04975^{* * *}$ & $0.9584^{* * *}$ \\
\hline$r^{2}$ & 99.1 & 94.1 & 99.2 \\
\hline $\begin{array}{l}\text { Regression } \\
\text { mean square }\end{array}$ & $39562.9^{* * *}$ & $237.9043^{* * *}$ & $44120.489^{* * *}$ \\
\hline $\begin{array}{l}\text { Residual } \\
\text { mean square }\end{array}$ & 5.206 & 0.1129 & 5.342 \\
\hline SE constant & 0.386 & 0.00108 & 0.391 \\
\hline SE slope & 0.0104 & 0.0000 & 0.0105 \\
\hline
\end{tabular}

et al. (2003). Root distributions were taken from literaturederived values (Gonçalves and Mello, 2004, Knight, 1999; Laclau et al., 2001; Nouvellon et al., 2002; O'Grady et al, 2005) and were validated from cores driven into the soil to a depth of $350 \mathrm{~cm}$ at 5 points in each of the 6 plots. Roots separated from the soil were dried and weighed to determine root mass per soil volume in layers of $0-5,5-15,15-3030-50,50-100$, and $50 \mathrm{~cm}$ increments thereafter, to $350 \mathrm{~cm}$. A root water uptake model (Feddes et al. (1978) was used to simulate root water uptake assuming transpiration to range between 1 and $6 \mathrm{~mm}$ per day (Dye, 1996; Nouvellon et al., 2002).

\section{Results}

\section{Rainfall and canopy drainage}

Annual rainfall for the first 2 years of the study was below the site long-term average $(920 \mathrm{~mm})$. Rainfall measured between October and October of each year was $696 \mathrm{~mm}$ for 2009, $721 \mathrm{~mm}$ for 2010, and $918 \mathrm{~mm}$ for 2011, in the 2 years. Linear regression analysis between rainfall, throughfall, stemflow and canopy drainage (Table 2) indicated that around $90 \%$ of rainfall penetrates the canopy as throughfall after the initial $1.4 \mathrm{~mm}$ of interception, while a further $5 \%$ of rainfall penetrates as stemflow. Interception as a percentage of rainfall was dependant on rainfall intensity, with large rainfall events resulting in a low interception percentage $(0.25 \%$ with $218 \mathrm{~mm})$ and small rainfall events resulting in a high interception percentage $(100 \%$ with $1 \mathrm{~mm})$. Coefficient of variation (CV) between throughfall collectors averaged at $6.2 \%$ and remained below $15 \%$ for the 
duration of the study. Smaller rainfall events (below $3.5 \mathrm{~mm}$ ) produced the largest variability between collectors. Stemflow volume increased with tree size (dbh) and was correlated with rainfall (a statistical correlation (R) of 0.93 to 0.95 between collectors). On a few occasions a small amount of precipitation was collected under the tree canopy without rainfall (possibly from dew or mist interception).

A mass of $26 \mathrm{t} \cdot \mathrm{ha}^{-1}\left(2.6 \mathrm{~kg} \cdot \mathrm{m}^{-2}\right)$ of harvest residue remained on the site after harvesting. This was added to the pre-existing $24.6 \mathrm{t}^{\mathrm{h}} \mathrm{ha}^{-1}$ $\left(2.5 \mathrm{~kg} \cdot \mathrm{m}^{-2}\right)$ of forest floor during harvesting to yield $50.6 \mathrm{t} \cdot \mathrm{ha}^{-1}\left(5.1 \mathrm{~kg} \cdot \mathrm{m}^{-2}\right)$ of residue. The 3-month delay between felling and burning resulted in a large portion (28\%) of the residues decomposing prior to burning. Burning reduced the remaining residue from $36.4 \mathrm{tha}^{-1}$ $\left(3.6 \mathrm{~kg} \cdot \mathrm{m}^{-2}\right)$ to $4.2 \mathrm{t} \cdot \mathrm{ha}^{-1}\left(0.4 \mathrm{~kg} \cdot \mathrm{m}^{-2}\right)$, a layer of ash and char that did not persist on the soil surface after the first week after burning, during which $15 \mathrm{~mm}$ of rainfall fell. Only a very small quantity of coarse char remained on the soil surface in small mounds, the remainder leached into the soil with larger particles creating a distinctive char horizon between 5 and $10 \mathrm{~cm}$ from the soil surface. The soil surface thereafter was predominantly ash-free with only white sand visible.

\section{Change in soil moisture after harvesting}

Soil moisture content is presented in Fig. 4 (a) - (c) as the mean and standard deviation of data sets from 10 probes' data in each treatment. Soil moisture recharge in the felled plots began within 1 month after felling (and 72 $\mathrm{mm}$ of rainfall) at shallow depths and after 3 months at $100 \mathrm{~cm}$ with a further $230 \mathrm{~mm}$ of rainfall. Recharge in the standing crop plots, although often less than in the felled areas, was rapidly reduced after rainfall during the first few summer months after felling (Fig. 4a - c). During each winter of the study in the SC treatment water content near $100 \mathrm{~cm}$ depth remained at a level slightly above wilting point despite being reduced to wilting point at the shallower depths. This may indicate a reduction in root activity at this depth during winter. Soil moisture contents in the No-Burn and Burn treatments were consistently higher than the SC treatments and seemed to remain above field capacity for a period of approximately 2 months during the inter-rotational period, even during prolonged periods without rainfall. Differences in soil moisture content between residue management treatments, although relatively small, remained consistent throughout the inter-rotational period. The No-Burn treatment remained moister than the Burn treatment with up to $3 \%$ higher water content after burning during the period from felling to about 6 months of age of the new crop. Differences in soil moisture content between the SC and both the Burn and No-Burn treatments decreased as the new crop approached canopy closure. Soil moisture measurements after canopy closure were slightly higher in the No-Burn treatment than the Burn treatment, while soil moisture in both Burn and No-Burn plots tended to remain below that of the SC treatment.

Variability (standard deviation) between probes and CV within each treatment plot was linked primarily to the probe position relative to the trees. Probes at the centre of 4 trees reflected greater wetting after rainfall and more rapid subsequent drying than probes positioned near to trees. Standard deviations and CV across all probes at each depth within each residue management treatment were also greater after rainfall as differences in soil moisture content between probe positions relative to the trees became more exaggerated. This was most apparent in the SC treatment and least apparent in the felled treatment plots during the inter-rotation period, variability being greater in the Burn treatment at the soil surface. Variability between probe positions began to decrease to similar levels as the SC treatments as new crop growth progressed. The CV between probe positions remained below $15 \%$ at the soil surface, decreasing with depth to below $5 \%$ as differences between probe positions became less. Measured water contents obtained via probes and gravimetric determination agreed well, 


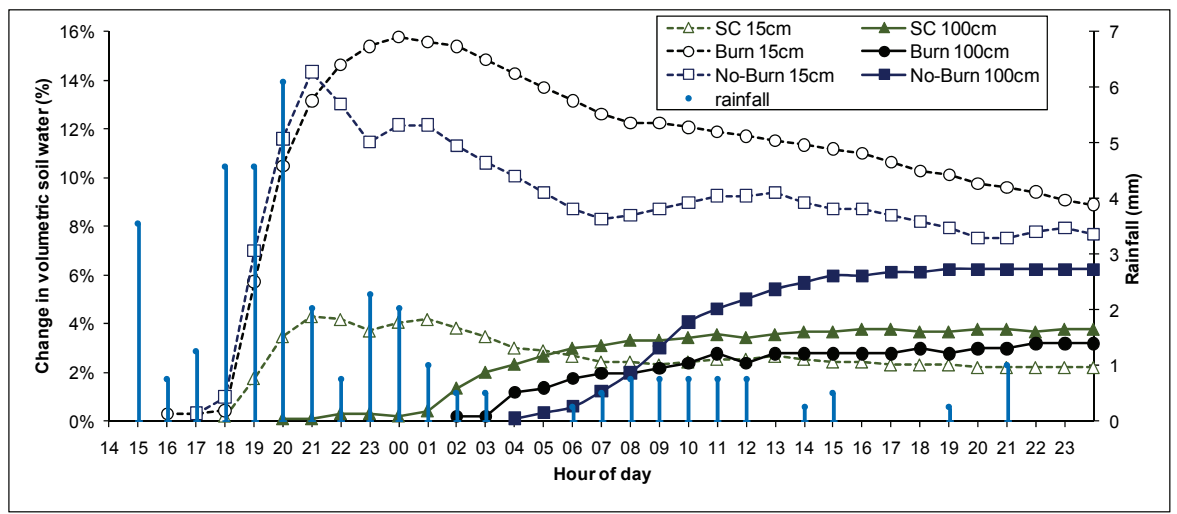

Figure 5

Demonstration of the time delay between wetting front detection at $15 \mathrm{~cm}$ and $100 \mathrm{~cm}$ as percentage change in soil moisture content after onset of rainfall in the standing crop (SC), residue burned (Burn) and residue retained (No-Burn) treatments. Calculated as difference from pre-rainfall soil moisture content (zero values not shown).

indicating adequate probe calibration for the site. Differences in wetting and drying patterns between probe positions may have been due to limited runoff and run-on across the microtopography of the site. Rapid drying may have been through higher root densities in the wetter depressed zones (Laclau et al., 2001).

Although water use was apparently high in the SC, very little growth occurred during the study period, with the biomass increasing by $4.6 \%\left(4.2 \mathrm{t}^{-\mathrm{h}^{-1}}\right)$ during the first year after planting the new crop. While stem wood accounted for $3.2 \mathrm{tha}^{-1}$ of this growth litterfall added a further $7.7 \mathrm{tha}^{-1}$ to above-ground biomass production in the SC during this period. Leaf area index was calculated as $1.68 \mathrm{~m}^{2} \cdot \mathrm{m}^{-2}$ across the site at felling, fluctuating between 1.75 in the wet season and 1.42 in the dry season of the unfelled plots. Water-use efficiency for stem wood production was therefore poor, given the high rate of water loss and limited growth. New crop growth was initially greater in the Burn treatment than in the No-Burn treatment, but slowed in the Burn treatment after canopy closure. Differences in biomass in the Burn treatment compared with the No-Burn treatment amounted to $29 \%$ more at 6 months, $17 \%$ more at 1 year and 5\% more at 18 months. Although biomass in the Burn and No-Burn treatments was not statistically different from 18 months onwards, growth in the Burn treatment continued to slow relative to the No-Burn treatment. Leaf area index was measured as 1.9 and 1.5 in the Burn and No-Burn treatments, respectively, at 6 months of age and 2.7 and 2.4, respectively, at 1 year (canopy closure). An above-ground biomass of 4.1 and $3.1 \mathrm{t}^{-\mathrm{ha}^{-1}}$ was estimated in the Burn and No-Burn treatments, respectively, at 6 months of age, and 11.5 and 9.9 tha $^{-1}$ at 1 year after planting.

During the inter-rotation to canopy closure period at 3 to 14 months after clearfelling (February 2009 to April 2010), hourly TDR and weekly profile probe soil moisture data gave some evidence indicating an alteration in soil hydraulic conductivity (infiltration rate) and field capacity in the felled No-Burn and Burn treatments. These parameters were not measured directly during this period as this change was not expected. Hourly TDR data produced consistent wetting-front advance rates on each test plot for a number of rainfall events prior to felling across all treatments, and throughout the study period for the SC treatment. Fig. 5 presents evidence of a wetting front (using TDR probe measurements) after a prolonged dry period and the onset of evening rainfall. An evening sample of the TDR data was selected to reduce the potential effects of daytime evapotranspiration. A wetting front was detected at $100 \mathrm{~cm}$ depth within 2 to $3 \mathrm{~h}$ of detection of increased moisture at $15 \mathrm{~cm}$, in agreement with the expected time for water to move this distance through the profile for the given soil hydraulic conductivity of the soil. After felling and during the inter-rotational period (Fig. 5), wetting front rates slowed in the felled Burn and No-Burn treatment plots while remaining unchanged in the SC treatment plots. The decrease in rate of the wetting front velocity was most apparent from around 3 months after felling in the Burn and No-Burn treatments, becoming less apparent over the months that followed. Penetration time in the water drop repellency test was found to vary by a few seconds, though no significant difference $(\mathrm{P}<0.05)$ was found between treatments (data not shown). This suggested that the water repellency of the soil did not alter water infiltration rates between treatments, though the infiltration rate may have been affected by soil surface condition (presence or absence of residue and site micro-topography).

\section{Water collected by plate lysimeters}

Fig. 6 (a) to (c) presents mean volumes of water collected at 15, 50 and $100 \mathrm{~cm}$ depths by the plate lysimeters; Fig. 7 presents the total volumes of water collected by the plate lysimeters at each depth, compared between treatments for periods between felling and residue burning, burning and 6 months after planting, 6 months and canopy closure (12 months) and canopy closure to 18 months after planting. Cumulative rainfalls during each time period were 418, 211, 641, 286 and $727 \mathrm{~mm}$, respectively. Volumes of water collected decreased with depth and were generally the lowest in the SC treatment. Larger total volumes of water were collected under the Burn treatment at each depth than under the No-Burn treatment. Despite the trends of differences between treatments, no significant $(P<0.05)$ differences between treatments were found. The volumes of water collected were dependent on soil moisture content prior to rainfall events and the intensity of each rainfall event. Low-intensity rainfall events resulted in more water collection than similar-quantity high-intensity rainfall events, as the lower intensity of rainfall may have reduced the fraction of water lost by plates overflowing.

\section{Predicted water content using Hydrus model}

Table 3 presents the linear regression variables and relationships between water content predicted with the Hydrus model and that measured within the profile probe at each depth for the SC plots. The model adequately estimated water content at all depths with a near 1:1 relationship between predicted and observed values. Model estimates were poorer at the soil surface, but improved with soil depth; this is reflected in the increase in the $r^{2}$ values with increasing depth. Soil surface estimations may have been less reliable as the surface soils 


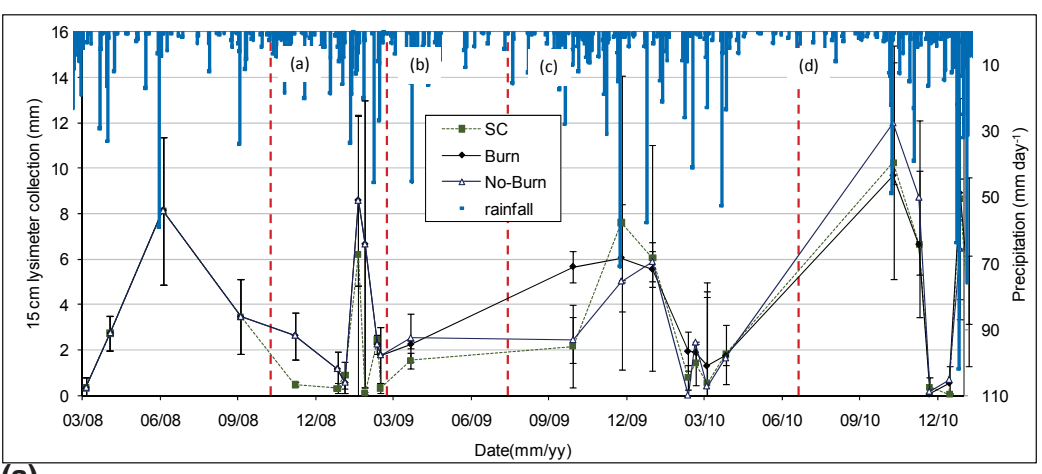

(a)

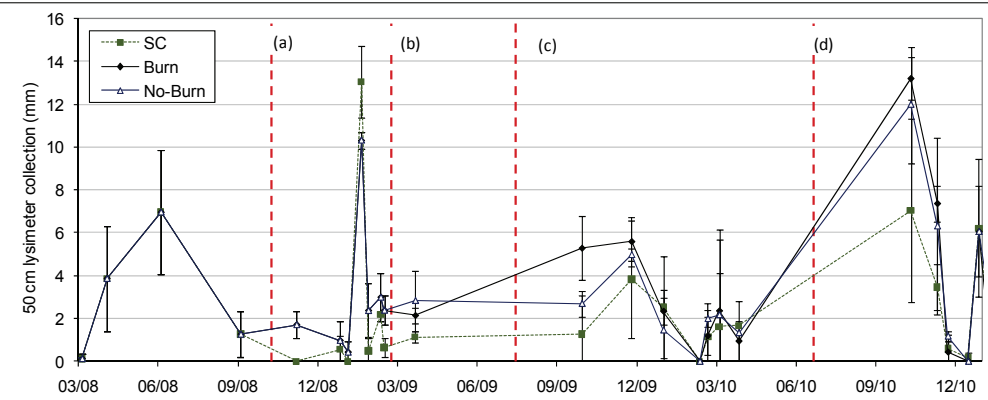

(b)



(c)

Figure 6a-c

Mean volumes $( \pm S D$ ) of water collected at 15,50 and $100 \mathrm{~cm}$ depth with plate lysimeters in the standing crop (SC), residue burned (Burn) and residue retained (No-Burn) treatments. Dashed lines represent (a) felling; (b) residue burning; (c) planting and (d) canopy closure. I bars represent single standard deviations. Rainfall events are shown as vertical lines scaling to an inverted secondary $Y$ axis in 6a.

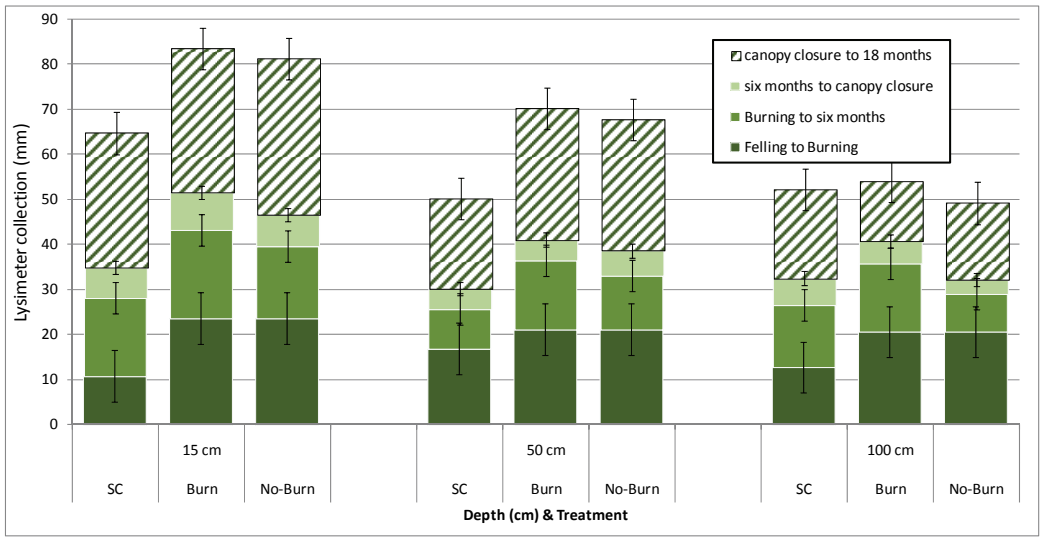

Figure 7

Total volume of water collected at 15, 50 and $100 \mathrm{~cm}$ depth with plate lysimeters in the standing crop (SC), residue burned (Burn) and residue retained (No-Burn) treatments, from felling to 18 months after planting. Stacked bars represent time periods from felling to burning, and 6-monthly time periods from planting to canopy closure onwards. I bars represent $5 \%$ least significant differences for treatment and collection period. had more variable organic carbon content and lower bulk density, especially in the 0 to $10 \mathrm{~cm}$ soil layer. A further estimation of soil moisture content to $10 \mathrm{~m}$ depth was performed for the SC treatment, assuming constant soil properties to depth and the absence of a water table above $10 \mathrm{~m}$ depth. The model estimated no drainage beyond 2 to $3 \mathrm{~m}$ depth, assuming all water to be taken up by the standing crop. However, this was not validated with actual measurements.

Model predictions of water content were poorer than the SC for the No-Burn and Burn treatments during the inter-rotation to canopy closure period, 3 to 14 months after clearfelling. Predicted water content during this period was significantly below values measured in the field. Reducing soil hydraulic conductivity and increasing field capacity in the Hydrus 1D model, for the period in question, to levels determined with the probe measurements improved the model's predictive capabilities. An inverse model prediction of soil hydraulic properties was also used to produce improved soil moisture estimation. Although adjusting soil hydraulic conductivity in the Hydrus 1D model allowed for a much closer fit between predicted and observed soil moisture content during this time period, changes in other hydraulic parameters could only be estimated. Fig. 8a and Fig. 8b present the Hydrus 1D predicted total volumes of water passing the 15, 50 and $100 \mathrm{~cm}$ soil depths for the duration of the study for the unfelled and felled treatments areas. Values in Fig. 8b are total volumes from felling to 18 months after planting, subdivided into time periods similar to Fig. 7. Drainage volumes as predicted by Hydrus (Fig. 8b) were higher than those measured in the field (Fig. 7). Actual drainage was 4 to $6 \%$ of predicted drainage in the felled plots, and 6 to $27 \%$ of predicted values in the unfelled plots. Plate drainage rate may have been too slow and water may have been diverted around the plates or by plates overflowing, an occurrence common in such lysimetery studies (Weihermuller et al., 2007).

\section{Discussion}

This study shows the changes in soil moisture regimes after clearfelling a clonal eucalypt crop on the well-drained sandy soils of the Zululand coastal plain. While soil moisture recharge did occur to field capacity under the living tree canopy, soil moisture was rapidly reduced over the entire measured soil profile through evapotranspiration. Changes in soil moisture after clearfelling indicated rapid soil moisture recharge with rainfall after clearfelling; with surface evaporation and weed and coppice re-growth 


\begin{tabular}{|l|c|c|c|c|c|c|}
\hline \multicolumn{7}{|c|}{$\begin{array}{c}\text { Table 3 } \\
\text { Relationships between water content predicted with the Hydrus 1D model and measured } \\
\text { with the profile probe at each depth for the standing crop (SC) treatments }\end{array}$} \\
\hline Statistic & $\mathbf{1 0} \mathbf{~ c m}$ & $\mathbf{2 0} \mathbf{~ c m}$ & $\mathbf{3 0} \mathbf{~ c m}$ & $\mathbf{4 0} \mathbf{~ c m}$ & $\mathbf{6 0} \mathbf{~ c m ~}$ & $\mathbf{1 0 0} \mathbf{~ c m}$ \\
\hline Constant & $-0.00016^{\text {ns }}$ & $0.00002^{\text {ns }}$ & $0.00002^{\text {ns }}$ & $-0.00009^{\text {ns }}$ & $-0.00034^{\text {ns }}$ & $-0.00003^{\text {ns }}$ \\
\hline Slope & $1.0046^{* * *}$ & $1.0023^{* * *}$ & $1.0023^{* * *}$ & $1.004^{* * *}$ & $1.0081^{* * *}$ & $1.0000^{* * *}$ \\
\hline$r^{2}$ & 79.9 & 80.1 & 80.1 & 81.9 & 80.3 & 86.3 \\
\hline Regression Mean square & $0.01512^{* * *}$ & $0.02145^{* * *}$ & $0.02145^{* * *}$ & $0.02333^{* * *}$ & $0.02309^{* * *}$ & $0.01673^{* * *}$ \\
\hline Residual Mean square & 0.00007 & 0.0001 & 0.0001 & 0.00009 & 0.0001 & 0.00005 \\
\hline SE Constant & 0.00394 & 0.00421 & 0.00421 & 0.00395 & 0.00406 & 0.00302 \\
\hline SE Slope & 0.0684 & 0.0678 & 0.0678 & 0.064 & 0.0678 & 0.0541 \\
\hline
\end{tabular}

*** Superscrip t implies $F$ - or T-test significance at $P<0.001$; ns superscript implies no significance

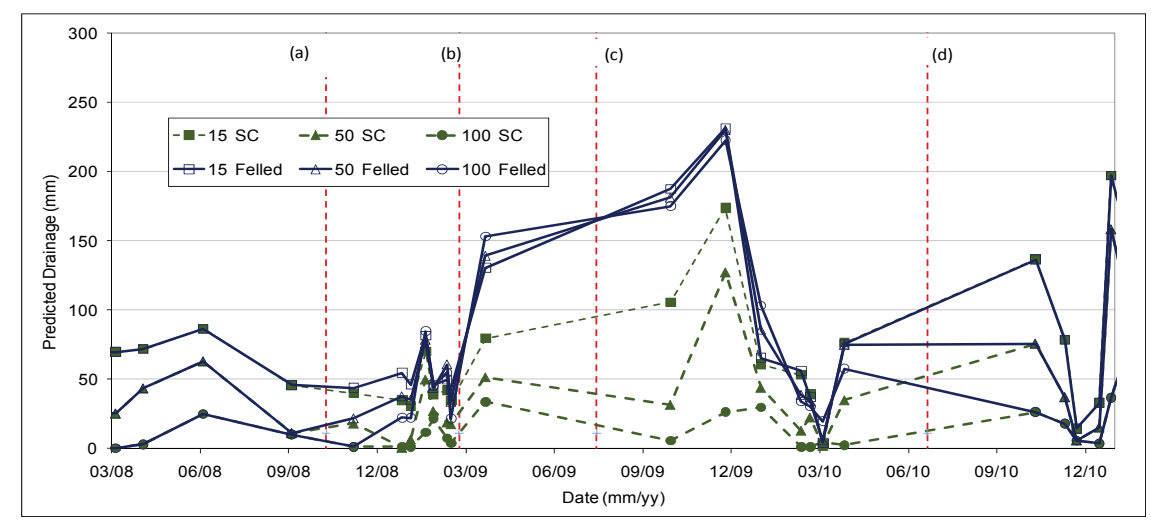

Figure 8a

Predicted drainage volumes at 15, 50 and $100 \mathrm{~cm}$ for felled and standing crop

(SC) areas of the study site. Vertical dashed lines represent (a) felling; (b) residue burning; (c) planting and (d) canopy closure.

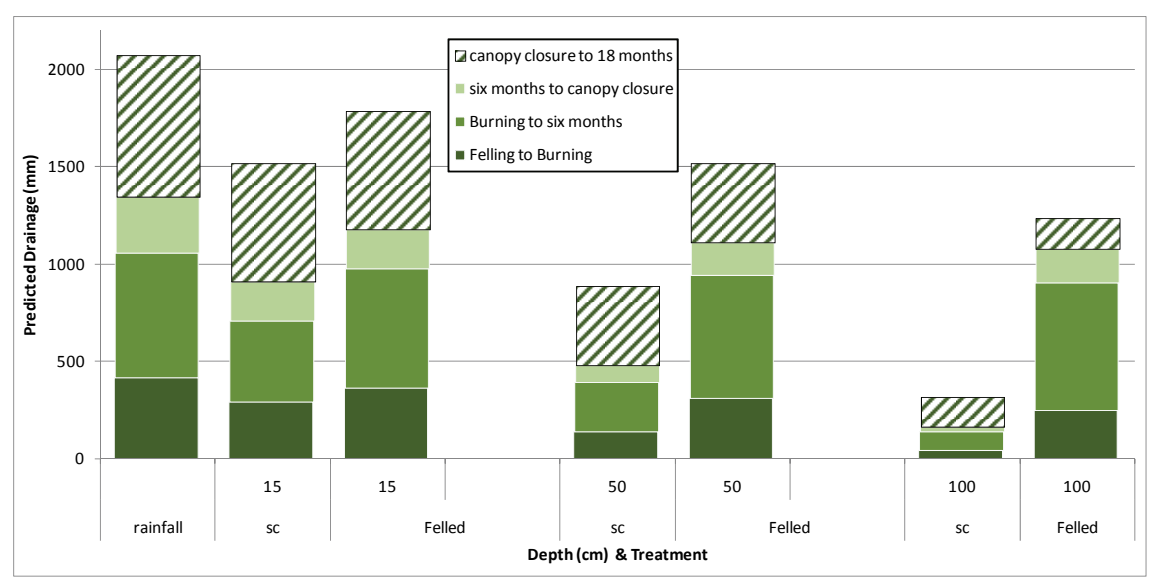

Figure $8 b$

Rainfall and predicted drainage volumes at 15, 50 and $100 \mathrm{~cm}$ for felled and standing crop (SC) areas of the study site. Each portion of the bars represents drainage predicted for each period in Fig. 8.

reducing soil moisture content. The increased soil moisture status after harvesting was temporary as the new trees had developed a relatively large leaf area by the time of canopy closure that afforded a rapid reduction in soil moisture in the upper soil layers. The residue layer on the No-Burn treatment and the absence of this layer on the Burn treatment (with exposed sand) may have been responsible for the small differences in soil moisture content. The retention of residue results in both higher interception of rainfall prior to entering the mineral soil and lower soil surface evaporation rates. Burning eliminated interception of rainfall prior to entering the mineral soil, but increased soil surface evaporation rates through surface exposure. These may have effectively reduced overall measured differences between Burn and No-Burn treatments.

Although soil moisture levels in the new crop were similar to those in the SC crop by canopy closure, relatively faster soil moisture depletion occurred under the larger canopy of the new crop, particularly in the Burn treatment. Despite the increased canopy leaf area after burning having a relatively larger water demand, the additional growth in this treatment 
may imply increased water use efficiency with respect to biomass production. This early biomass increase is often used by plantation managers as an incentive towards residue burning. The faster-developing canopy reduces weed growth, thereby reducing operational weeding costs. This increase in biomass was short-lived in this study, as growth in the burned plots began to decline relative to the unburnt plots after canopy closure. An increased leaf area after burning may have reduced the new crop's ability to cope with water deficits or drier soil conditions after canopy closure, hence reducing growth rates. This may imply that trees that have developed a larger canopy in response to residue burning may have a reduced ability to cope with drought conditions, should these occur.

Not all processes that affect soil hydrology are clearly understood or accounted for in plantation forest hydrological models. Stemflow has been shown to channel water and nutrients captured during rainfall or mist events directly to tree root systems, providing water to trees that is often not detected in the bulk soil or accounted for in hydrological models (Johnson and Lehmann 2009). Preferential flow along old tree root channels as a mechanism of sub-surface wetting or groundwater recharge may also be poorly accounted for (Le Maitre et al., 1999). The interactions between pest infestation and water use efficiency may also need investigation, particularly where pests cause no reduction in leaf area, but increase leaf water loss through damage to epidermal leaf tissue or photosynthetic capacity. The continued water use during pest infestation and the drastic reduction of growth in this study clearly demonstrates the negative impact and cost of pest infestation to productivity and water use efficiency.

Organic substances released from the rapidly-decomposing residues may have played a role in altering the soil during the inter-rotation. Organic exudates, root decomposition, proliferation of fungal hyphae and microbial biomass in the soil may have temporarily altered soil physical properties and disrupted hydraulic flow paths through biological soil-pore clogging. Research has shown that organic matter has a strong influence on water retention and saturated hydraulic conductivity (Rawls et al., 2003). Blanco-Canqui and Lal (2007) presented evidence of mulches added to the soil surface causing an increase in soil porosity and soil moisture content at wilting point and a decrease in soil bulk density. Changes in hydraulic conductivity induced through microbial activity have also been shown in column studies that simulated saturated soils (Seki et al. 1998), although these effects associated with forest residue breakdown need to be confirmed with further study. A water-repellent layer in the soil, produced by fine char particles, may also act to increase the water retention characteristics of a soil (Moore 1996; Onodera and Stan, 2011; Woods and Balfour, 2010).

Large quantities of nutrients locked up in the residues are rapidly released through residue decomposition into the soil solution during the inter-rotational period. Solutes may be displaced beyond the shallow fine-rooting zone or lost where large quantities are further leached. This may be a concern where nutrient replacement through natural processes occurs at insignificant rates and where fertilisation is not possible. Although high evapotranspiration rates and water use of eucalypts, which can lead to decreased stream flow, are a disadvantage on water-limited sites where there are other competing human, agricultural, industrial or environmental requirements for water, high evapotranspiration rates and water use may limit nutrient loss from plantation forests. This may be of importance to infertile sites where loss or displacement of nutrients with drainage can negatively affect growth. This principle was demonstrated in studies conducted on the sandy soils of Congo and Brazil where water did not drain beyond a depth of $5 \mathrm{~m}$, despite a far higher rainfall than than recorded for the present study site (Nouvellon et al., 2002). The loss of nutrients in that study had a far more negative effect than the loss of water. Sites at risk of nutrient loss may therefore require special management. Allowing temporary coppice regrowth and planting to achieve earlier canopy closure may limit drainage and nutrient leaching loss that may occur if plantation areas are left fallow for prolonged periods.

\section{Conclusion}

Despite the disadvantages of high water use, an implied reduction in nutrient leaching or displacement under a full-canopied crop may allow more nutrients to be retained in the active rooting zones under the undisturbed forest stand. The impact of pest damage on water use efficiency in the full-canopied crop may also need further investigation, as the loss to productivity, coupled with the high cost of water, compounds economic losses related to water use. Although soil moisture and drainage increased after felling, differences between residue retention and residue burning presented here may not be enough to affect the decision between burn and no-burn management policies. Based on data presented here, it is also unlikely that the residue management practices presented here will have any further direct impacts on soil moisture content and drainage beyond the period presented in this study. Reducing water use through increases in productivity as a consequence of superior genetics and clonal forestry may still be one of the best strategies for improving water use efficiency, essentially producing more timber per unit water use (Stape et al., 2004). The possibility of increased water use resulting from a potentially larger tree canopy, induced in response to planting after residue burning, may however increase the drought susceptibility of the new crop around the time of canopy closure. Deeper drainage and leaching or displacement of nutrients during the period directly after clearfelling may be of concern to forest managers for sites that are sensitive to soil nutrient losses. This may give reason for plantation forest managers to shorten the inter-rotation length, with earlier planting to enable a more rapid depletion of soil moisture through earlier canopy closure, thereby retaining more nutrients in the soil and in the growing trees. This, however, may only be necessary for sandy soils with a low nutrient retention capacity. Rapid replanting is obviously also positive from a financial point of view.

In addition to soil carbon and nutrient loss with biomass removal and burning, reducing drainage loss or the displacement of nutrients on sites with low water and nutrient storage capacity may be an important factor driving the efficient, and ultimately the sustainable, use of water and nutrient resources of such sensitive sites.

\section{Acknowledgements}

The senior author would like to thank the ICFR member companies who funded the core project (Mondi, Sappi, SiyaQhubeka, NCT, TWK), SiyaQhubeka and staff and contractors for the time and effort they placed in supporting this study, and the Stellenbosch University Forestry Department staff for encouraging me to publish work outside of my field of expertise. My gratitude goes to the Director and staff of the ICFR for their support and encouragement, Jean-Paul Laclau (Univ. ESALQ, Brazil) for his insight and inspiration, and Colin Smith for his project supervision and support. Special 
thanks to Denis Oscroft and the Zululand technical team for their excellent management of the field experiment and to Nkosinathi Kaptein for sample and data management. Finally, I would like to thank the anonymous referees for their generous and encouraging contributions to this manuscript.

\section{References}

BLANCO-CANQUI H and LAL R (2007) Impacts of long-term wheat straw management on soil hydraulic properties under no-tillage. Soil Sci. Soc. Am. J. 71 (4) 1166-1173.

CARLYLE JC and NAMBIAR EKS (2001) Relationships between net nitrogen mineralization, properties of the forest floor and mineral soil, and wood production in Pinus radiata plantations. Can. J. For. Res. 31 (5) 889-898.

COETZEE J (1992) Site index curves for E. grandis stands managed by SAPPI Forests in the Nelspruit region. ICFR Bulletin Series 20/92. Institute for Commercial Forestry Research, South Africa.

DEBANO LF (2000) Water repellency in soils: a historical overview. J. Hydrol. 231-232 4-32.

DYE P and VERSFELD D (2007) Managing the hydrological impacts of South African plantation forests: An overview. For. Ecol. Manage. 251 (1-2) 121-128.

DYE PJ (1996) Response of Eucalyptus grandis trees to soil water deficits. Tree Physiol. 16 (1-2) 233-238.

DYE PJ, JACOBS S and DREW D (2004) Verification of 3-PG growth and water-use predictions in twelve Eucalyptus plantation stands in Zululand, South Africa. For. Ecol. Manage. 193 (1-2) 197-218.

FEDDES RA, KOWALIK PJ and ZARADNY H (1978) Simulation of Field Water Use and Crop Yield. Simulation Monographs. PUDOC, Wageningen. $189 \mathrm{pp}$.

FEY M and HUGHES J (2010) Soils of South Africa. Cambridge University Press, Cape Town. 288 pp.

FSA (2009) Abstract of South African Forestry Facts for the Year 2007/8. Forestry South Africa, Pietermaritzburg.

GONÇALVES JLM and MELLO SLM (2004) The root system of trees. In: Gonçalves JLM and V Benedettis (eds.) Forest Nutrition and Fertilization. IPEF, Piracicaba. 223-267.

HARTEMINK AE and HUTTING J (2005) Sandy soils in Southern and Eastern Africa: extent, properties and management. In: Proc. Management of Tropical Sandy Soils for Sustainable Agriculture. A Holistic Approach for Sustainable Development of Problem Soils in the Tropics, 27 November - 2 December 2005, FAO Regional Office for Asia and the Pacific, Khon Kaen, Thailand. 148-158.

JOHNSON MS and LEHMANN J (2009) Double-funneling of trees: Stemflow and root-induced preferential flow. Ecoscience 13 (3) 324-333.

KIENZLE SW and SCHULZE RE (1992) A simulation model to assess the effect of afforestation on groundwater resources in deep sandy soils. Water SA 18 (4) 265-272.

KIMMINS JP (1973) Some statistical aspects of sampling throughfall precipitation in nutrient cycling studies in British Columbian coastal forests. Ecology 54 (5) 1008-1019.

KNIGHT JH (1999) Root distributions and water uptake patterns in Eucalypts and other species. In: Landsberg J (ed.) The Way Trees Use Water. Water and Salinity Trends. Agroforestry No. 5, RIRDC Publication No. 99-37. Rural Industries Research and Development Corporation, Kingston, Australia. 66-102.

LACLAU J-P, ARNAUD M, BOUILLET J-P and RANGER J (2001) Spatial distribution of Eucalyptus roots in a deep sandy soil in the Congo: relationships with the ability of the stand to take up water and nutrients. Tree Physiol. 21 (2-3) 129-136.

LACLAU JP, DELPORTE P, RANGER J and SAFOU-MATONDO R (2007) Modifications of the biogeochemical cycles of nutrients in a congolese savanna after afforestation with Eucalypts. In: Verne NC (ed.) Forest Ecology Research Horizons. Nova Science Publishers, New York. 1-38.

LAWRENCE GB and FERNANDEZ IJ (1993) A reassessment of areal variability of throughfall deposition measurements. Ecol. Appl. 3 (3) $473-480$.
LE MAITRE DC, SCOTT DF and COLVIN C (1999) A review of information on interactions between vegetation and groundwater. Water SA 25 (2) 137-152.

LETEY J, CARRILLO MLK and PANG XP (2000) Approaches to characterize the degree of water repellency. J. Hydrol. 231-232 61-65.

LEVIA DF and FROST EE (2003) A review and evaluation of stemflow literature in the hydrologic and biogeochemical cycles of forested and agricultural ecosystems. J. Hydrol. 274 (1-4) 1-29.

MOORE PD (1996) Fire damage soils our forests. Nature 384 (6607) 312-313.

MORLEY T and LITTLE K (2011) Comparison of taper functions between two planted and coppiced eucalypt clonal hybrids, South Africa. New For. 43 1-13. doi: 10.1007/s11056-011-9275-7.

MULULO SATO A, DE SOUZA AVELAR A and COELHO NETTO AL (2011) Spatial variability and temporal stability of throughfall in a eucalyptus plantation in the hilly lowlands of southeastern Brazil. Hydrol. Processes 25 (12) 1910-1923.

NADEL R, SLIPPERS B, SCHOLES M, LAWSON S, NOACK A, WILCKEN C, BOUVET J and WINGFIELD M (2010) DNA barcoding reveals source and patterns of Thaumastocoris peregrinus invasions in South Africa and South America. Biol. Invasions 12 (5) $1067-1077$.

NOUVELLON Y, BONNEFOND JM, HAMEL O, ROUPSARD O, MOUVONDY W, EPRON D, IRVINE M, BERBIGIER P, JOURDAN C, JOFFRE R, THONGO A, MABIALA A, DELEPORTE P, LACLAU JP, BOUILLET JP, MARIEN JN and DAUZAT J (2002) Project CARBOEUROFLUX: CO2 fluxes and carbon sequestration within Eucalypt stands in Congo. In: Proc. CarboEurope Meeting, 4-8 March 2002, Budapest.

O'GRADY AP, WORLEDGE D and BATTAGLIA M (2005) Temporal and spatial changes in fine root distributions in a young Eucalyptus globulus stand in southern Tasmania. For. Ecol. Manage. 214 (1-3) 373-383.

ONODERA S-I and STAN JT (2011) Effect of forest fires on hydrology and biogeochemistry of watersheds. In: Levia DF, Carlyle-Moses D and Tanakas T (eds.) Forest Hydrology and Biogeochemistry. Springer, Dordrecht. 599-621.

PAUL K (2003) Soil water under forests (SWUF): a model of water flow and soil water content under a range of forest types. For. Ecol. Manage. 182 (1-3) 195-211.

RAWLS WJ, PACHEPSKY YA, RITCHIE JC, SOBECKI TM and BLOODWORTH H (2003) Effect of soil organic carbon on soil water retention. Geoderma 116 (1-2) 61-76.

RIETZ DN (2010) The effects of compaction and residue management on soil properties and growth of Eucalyptus grandis at two sites in KwaZulu-Natal, South Africa. Ph.D. Thesis, University of KwaZulu-Natal, Pietermaritzburg. 332 pp.

SCHULZE RE (1997) South African Atlas of Agrohydrology and Climatology. WRC Report No. TT82/96. Water Research Commission, Pretoria, South Africa.

SCOTT DF (1993) The hydrological effects of fire in South African mountain catchments. J. Hydrol. 150 (2-4) 409-432.

SCOTT DF (2000) Soil wettability in forested catchments in South Africa; as measured by different methods and as affected by vegetation cover and soil characteristics. J. Hydrol. 231-232 87-104.

SCOTT DF and VAN WYK DB (1990) The effects of wildfire on soil wettability and hydrological behaviour of an afforested catchment. J. Hydrol. 121 (1-4) 239-256.

SEKI K, MIYAZAKI J and NAKANO T (1998) Effects of microorganisms on hydraulic conductivity decrease in infiltration. Eur. J. Soil Sci. 49 (2) 231-236.

ŠIMŮNEK J, ŠEJNA M, SAITO H, SAKAI M and VAN GENUCHTEN MT (2008) The Hydrus-1D software package for simulating the movement of water, heat, and multiple solutes in variably saturated media, Version 4.0. HYDRUS Software Series 3. Department of Environmental Sciences, University of California Riverside, Riverside. 315 pp.

SMETHURST PJ and NAMBIAR EKS (1990) Distribution of carbon and nutrients and fluxes of mineral nitrogen after clear felling a Pinus radiata plantation. Can. J. For. Res. 20 1490-1497. 
SMITH CW, PALLETT RN, KUNZ RP and GARDNER RA (2005) A strategic forestry site classification for the summer rainfall region of southern Africa based on climate, geology and soils. ICFR Bulletin Series 03/2005. Institute for Commercial Forestry Research, Pietermaritzburg, South Africa.

STAPE JL, BINKLEY D and RYAN MG (2004) Eucalyptus production and the supply, use and efficiency of use of water, light and nitrogen across a geographic gradient in Brazil. For. Ecol. Manage. 193 (1-2) 17-31.

TEN BERGE HFM (1986) Heat and water transfer at the bare soil surface: aspects affecting thermal imagery. Ph.D. Thesis, Wageningen Agricultural University, The Netherlands. 214 pp.
VAN GENUCHTEN MT (1980) A closed-form equation for predicting the hydraulic conductivity of unsaturated soils. Soil Sci. Soc. Am. J. 44 (5) 892-898.

WEIHERMULLER L, SIEMENS J, DEURER M, KNOBLAUCH S, RUPP H, GOTTLEIN A and PUTZ T (2007) In situ soil water extraction: A review. J. Environ. Qual. 36 (6) 1735-1748.

WOODS SW and BALFOUR VN (2010) The effects of soil texture and ash thickness on the post-fire hydrological response from ashcovered soils. J. Hydrol. 393 (3-4) 274-286. 